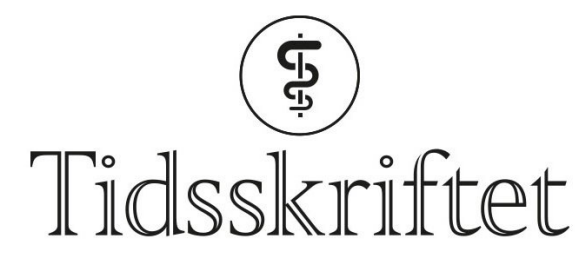

DEN NORSKE LEGEFORENING

\title{
Skriveglede og skapertrang
}

INTERVJU

MARIT TVEITO

E-post: marit.tveito@me.com

Psykiater og allmennlege Cecilie Arentz-Hansen er for mange norske leger like kjent for Legevakthåndboken som for å ha startet Lommelegen i dotcom-periodens første fase. Nå har hun skrevet en bok om Norges første kvinnelige leger - fordi hun synes de fortjener det.

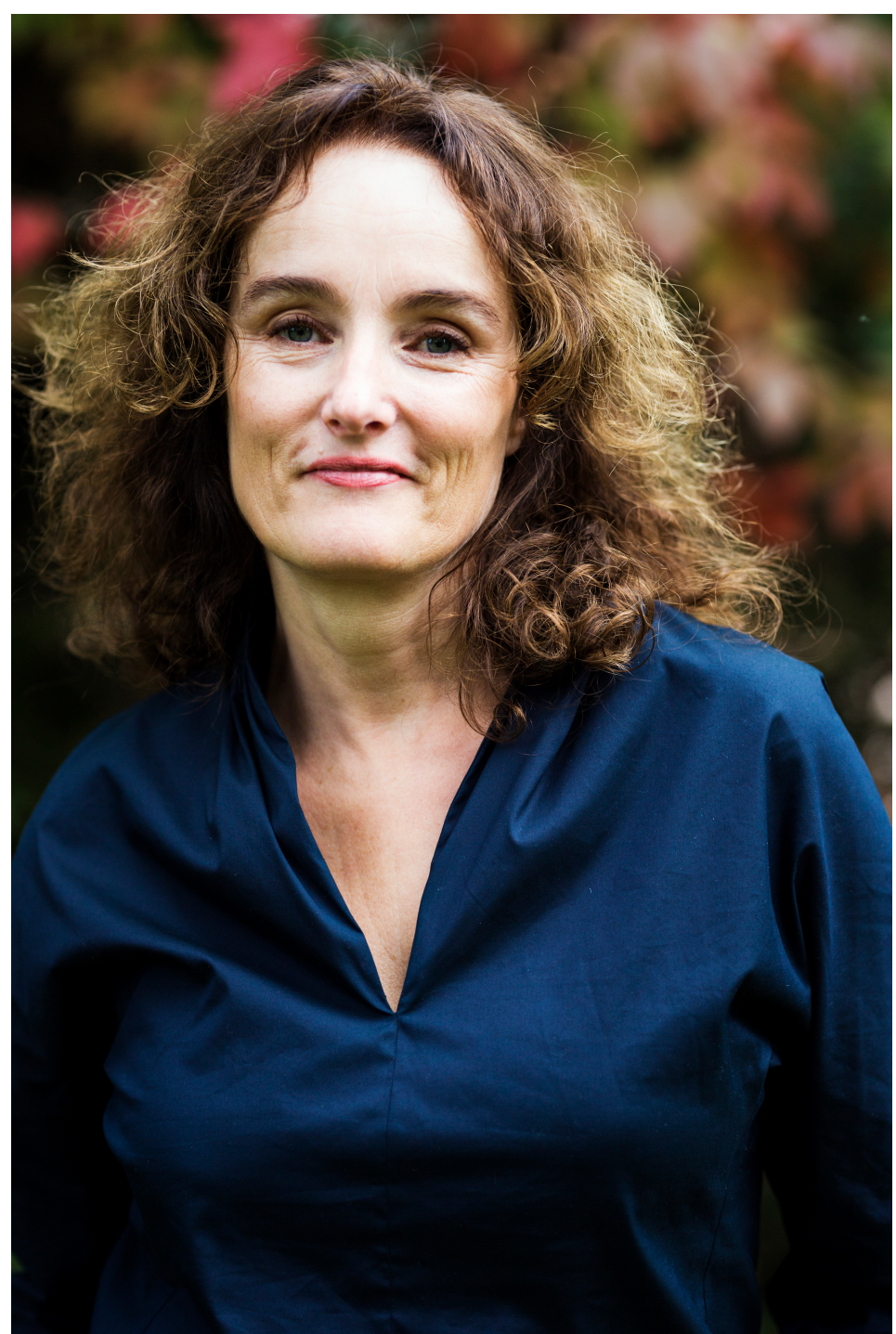

Alle foto: Kristine Lindebø 
Mild i vesen og sterk i person beskrives Cecilie Arentz-Hansen som. Venner og kolleger karakteriserer henne som en sjelden blanding av arbeidsjern og livsnyter, med lysende intelligens og høy gjennomføringsevne. Eneboligen på Stabekk ligger langt nok unna sentrum til at man får følelsen av å være på landet. I en romslig og frodig hage er det også et lite stabbur, kalt «skrivestuen». Med gjerde rundt hagen kunne Cecilie sitte inne i stabburet og skrive mens barna var små, med utsikt til leken gjennom vinduet. Hun var riktignok på jobb, så barna måtte lære at de skulle banke på døren før de gikk inn.

\section{En real, ordentlig jobb}

- Hvorfor ble du lege?

- Jeg bestemte meg tidlig, men hvor reflektert et valg er da ... Hun drar på det.

- Jeg vet ikke. Jeg tror jeg hadde en altruistisk motivasjon. Jeg tenkte dessuten at legeyrket var en real, ordentlig jobb. Jeg hadde lyst til å studere i utlandet og kom inn i Bonn.

- Kunne du like godt blitt noe annet?

- Jeg er fornøyd med valget, men har gått noen runder siden. Jeg fikk utløp for mye kreativitet da vi lagde Legevakthåndboken og startet Lommelegen. Nå er jeg leder for en poliklinikk og har bygget den opp fra bunnen. Kreativt er det kanskje ikke, men skapende i alle fall. Jeg har hatt de nødvendige rammer til å kunne bygge opp en poliklinikk på en måte jeg ønsker, en kveldspoliklinikk innen «raskere tilbake»-tilbudet.

- Hvordan har det vært å bygge opp noe fra scratch?

- Det har vært givende. Vi har pasienter som er i jobb, har blitt sykmeldt og ønsker seg raskt tilbake. Det er viktig å møte disse pasientene på en god måte. Behandler og pasient må se samme vei, ha et felles prosjekt. Det høres ut som en festtale, men samspillet er viktig. Så må det være høy faglig kvalitet på det arbeidet vi gjør.

\section{Masaispyd i spisestuen}

Da hun studerte i Tyskland, ble hun kjent med Kåre Moen, som var utvekslingsstudent fra Bergen. De fikk ideen til Legevakthåndboken i turnus. Han fikk tilbud om å være lege på et vannkraftanlegg i Tanzania og spurte Cecilie om hun ville bli med. De delte stillingen og skrev ferdig boken.

- Vi dro på tre ukers varsel. Først hadde vi skrevet noen kapitler og en disposisjon til boken, og vist det til en redaktør i Universitetsforlaget. Han sa vi bare skulle sette i gang. Her er forresten masaispydet mitt.

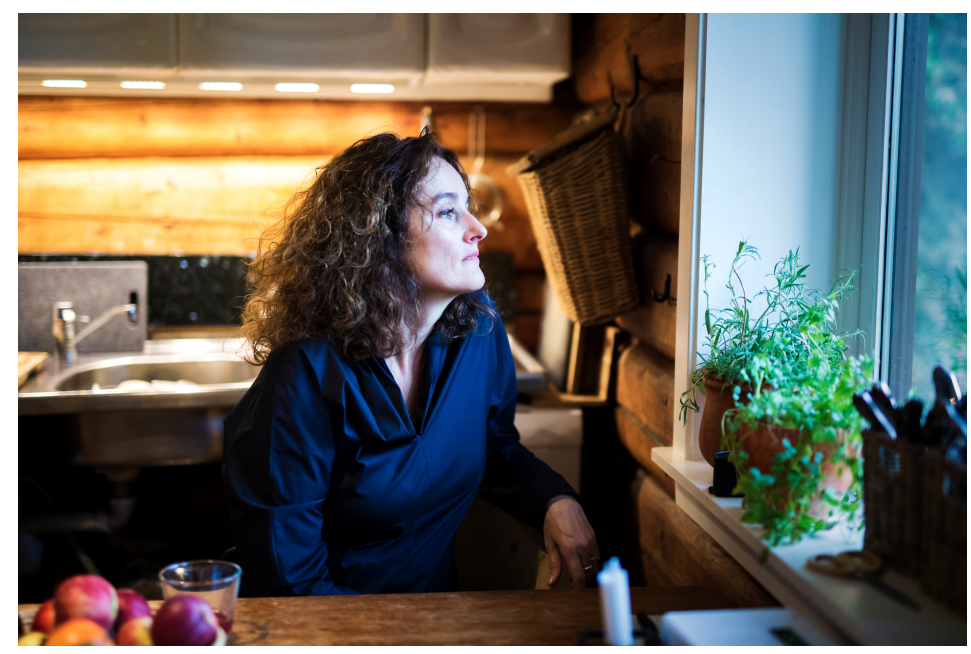

Det står litt unnselig i en krok like ved spisebordet. Langt, mørkt og spisst.

- En masai skal kunne drepe en løve med det, kommenterer hun tørt.

Nå står det til pynt i huset på Stabekk. Legelivet i Tanzania bød på mange erfaringer. 


\section{Cecilie Arentz-Hansen}

Født 27. september 1963

Grunnfag litteraturvitenskap i 1987

Cand.med. Bonn/Lübeck i 1989

Forfatter av Legevakthåndboken sammen med Kåre Moen i 1993

Startet Lommelegen AS sammen med Kåre Moen i 1998

Spesialist i allmennmedisin i 2007

Spesialist i psykiatri i 2013

Enhetsleder og overlege ved Raskere tilbake, Nydalen DPS, Oslo universitetssykehus, siden 2015

Ga ut boken «Kvinder med Begavelse for Lægevirksomhed» om Norges første kvinnelige leger i 2018

- Har det preget deg som lege?

- Mest som menneske, tror jeg. Det var som å komme til en verden man ikke visste fantes. Oppholdet var en stor berikelse og utvidet horisonten.

- Du og Kåre Moen har jobbet mye sammen?

- Vi inspirerte hverandre. En periode hadde vi hver vår del av en tomannsbolig og løp opp og ned trappen med bokkapitler.

\section{To poser sitroner}

Etter Afrika jobbet hun som allmennlege og med mange andre prosjekter, slik som å utarbeide informasjon om førstehjelp til ungdomsskoleelever.

- Du virker som en som ikke blir lei av jobben?

- Jeg tror man blir lei hvis man føler seg fanget. Det er viktig å kunne veksle på oppgavene, det gir energi. Autonomi gir motivasjon. Det å skape er viktig for meg. Nå sitter jeg ikke og skaper hele tiden, altså. Det å skrive en bok er mye rutinepreget arbeid også.

- En venn sa at du er flink til å finne lommer i hverdagen.

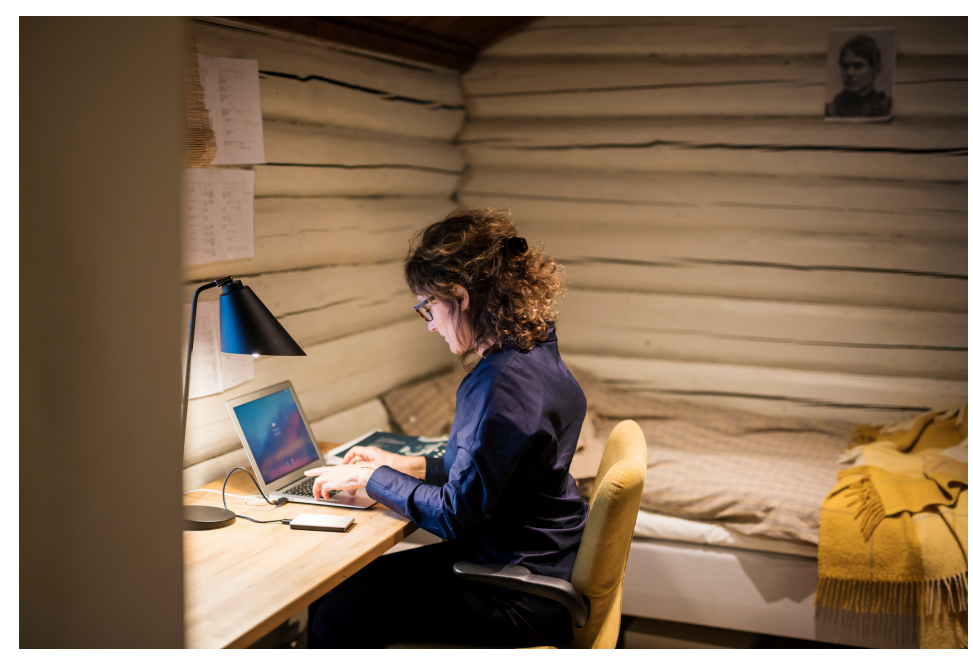

- Vi er så heldige å ha et hus i Italia. Det ligger i Liguria, i en liten landsby. Vi kom lett inn i dette lille samfunnet, for huset tilhørte min tante. Hun var et sosialt og utadvendt menneske, og kjente alle der. Jeg var «niesen til Katarina» fra jeg kom dit. Vi er del av et samfunn som er noe annet enn livet hjemme, og det er en berikelse. Hvis det er mye sitroner når vi er der, så kommer det to poser på døra. Eller tomater, aprikoser, squash, 
aspargesbønner ... Sjenerøsiteten er spesiell. De gir av sin overflod. Hvis noen blir syke, passer de på. Da hender det at jeg går og steller et sår.

- Du har et annet hjem?

- Ja, jeg føler det. Jeg er der så mye jeg kan.

Ektemannen beskriver henne som sanselig uten å være jålete, og sier at huset i Italia er en viktig del av henne. Hun er opptatt av farger og har innredet huset $i$ tråd med italiensk tradisjon. Arkitekten har blitt en god venninne.

\section{Dotcom}

-Så var dere tidlig ute med nettbasert helseinformasjon?

- Vi la ut noen tema om helse og fikk utrolig mange treff. Universitetsforlaget ble med, og vi fikk så mange treff at vi lå like under de store avisene. Schibsted kom etter hvert inn på eiersiden og skaffet midler til å bygge opp selskapet, og det åpnet seg muligheter for distribusjon. Jeg var redaksjonssjef. Det var midt i dotcom-bølgen, og mange hadde dollartegn i øynene. Vi holdt en nøktern stil og stod oss nok på det.

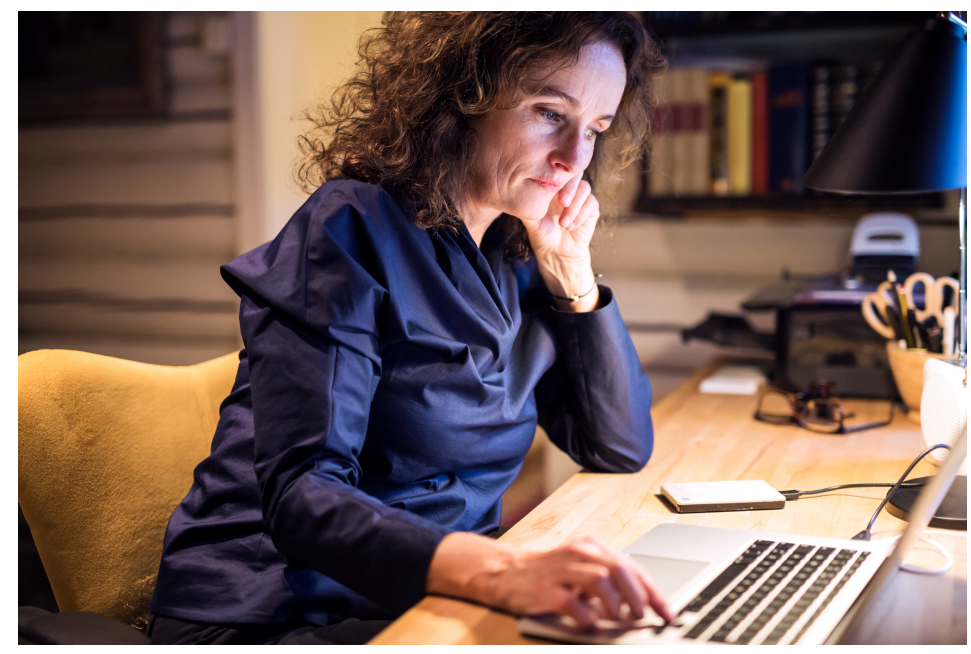

- Etter mange år som fastlege bestemte du deg for å jobbe med psykiatri?

- I allmennpraksis hadde jeg mange pasienter med depresjon, angst og kriser. Jeg likte psykiatridelen, og så ga det meg noe. Etter hvert sprang det frem et ønske om å bli psykiater.

En venn sa at Cecilie har et perfekt ansikt for en krisepsykiater: åpent og forståelsesfullt.

- Når folk er deprimerte eller i krise, så lukker verden seg, og mulighetene forsvinner. Det å være den som kommer utenfra og bidrar til å åpne opp igjen, gir mening. Den psykiske smerten i en depresjon er så sår. Det berører meg alltid. Det er vondt å være der den deprimerte er, hvor alt er grått og håpløst. Jeg synes det er givende å arbeide med denne pasientgruppen og organisere behandlingen de får.

\section{Frigjøringskamp}

- Hvorfor begynte du å skrive om de første kvinnelige legene i Norge?

- Jeg synes ikke det er riktig at vi har visst så lite om dem. De var veldig viktige. Da jeg tok eksamen i norsk på videregående i 1982, hadde Cecilie Thoresen tatt artium som første kvinne i Norge 100 år tidligere. Jeg var sikker på at vi skulle få en stiloppgave om henne til eksamen. Jeg forberedte meg på hennes historie og tiden hun levde i. Oppgaven kom aldri på eksamen, men det sådde nok et frø. Moren min har fortalt meg om Marie Holst, som var en av de første kvinnelige legene i landet. Hun jobbet i Trondheim. Da min morfar skulle ta over en legepraksis i Trondheim, flyttet hele familien dit med tog. På stasjonen stod Marie Holst og tok imot dem. Jeg har vært klar over at noen har gått foran. Deres historie kan si oss noe i dag. Det er andre kamper som foregår nå, men det er frigjøringskamper like fullt. En frigjøringshistorie er alltid unik, men den har elementer av gruppetenkning og motstanden 
kan ha noen likhetstrekk. Motstanden de første kvinnelige legene møtte, var fra medisinerne selv, den kom innenfra. Den var åpen, heldigvis, så jeg har kunnet lese om den, men det var også mye skjult motstand som jeg har funnet spor av i forarbeider og mindre offentlige dokumenter. Det kom argumenter som at kvinner ikke kunne tenke ordentlig, manglet dømmekraft og var i sine følelsers vold. Denne frigjøringskampen kan også være inspirerende i dag. Det har jo tross alt gått ganske bra med kvinnelige leger, sier hun, selv om ikke alt er perfekt.

\section{9 kvinner}

- Hvordan valgte du ut de 19 legene i boken?

- Jeg valgte de som var utdannet på 18oo-tallet, og jeg har kalt disse kvinnene den første generasjonen. Marie Spångberg var i 1893 den første kvinnen som fullførte medisinstudiet, og så har jeg tatt med de som fullførte studiet til og med 1900.

- Du har blitt godt kjent med historiene. Er det noen som har gjort sterkere inntrykk enn andre?

- En person som har vært viktig for Norges historie, er Marie Kjølseth. Hun er helt ukjent i dag, og det er vanskelig å forstå. Hun arbeidet for tryggere fødselshjelp og bedre barselpleie, og bidro til at en ny ekteskapslov ga kvinner bedre beskyttelse mot å bli smittet av kjønnssykdommer. Ikke minst gjorde hun en vesentlig innsats for kvinners stemmerett. Som lege var hun en dyktig kliniker og forsker. Da jeg fant en prisbesvarelse hun hadde skrevet, i Riksarkivets dyp, tror jeg ikke den hadde vært i lyset før. Arkene så fortsatt nye ut. I den får hun komplekse vurderinger til å virke enkle, og hun virker lite fanget av faglige sannheter i tiden hun levde i. Jeg opplevde å få en slags kontakt med hvem hun var da jeg leste det hun hadde skrevet. De første kvinnelige legene, deriblant Kjølseth, brukte mye krefter på undervisning og folkeopplysning. Mange holdt foredrag, og de var etterspurt.

- Da jeg leste boken, fikk jeg inntrykk av at disse kvinnene følte mye på ansvaret som fulgte med legegjerningen.

- Det er et tidstypisk fenomen. Privilegier forpliktet, og med rettigheter fulgte ansvar. De ville vise seg ansvaret verdig, og hadde en sterk etisk bevissthet. I tillegg skulle de tilføre samfunnet det beste av de kvinnelige verdiene, det var kvinnesakens imperativ. Medfølelse, medmenneskelighet, antimaterialisme og fredsfremmende arbeid ble for eksempel regnet som typisk kvinnelig. Jeg prøver å vise hvordan de forvaltet dette ansvaret gjennom ulike yrkeshistorier. Gudrun Kolderup er et eksempel på en lege som ga mye og ikke forventet noe tilbake. Jeg har snakket med folk i Ytre Arna der hun virket, og alle forteller det samme. Hun falt om i et sykebesøk. Da hun ble begravet, stoppet hele bygda opp.

\section{Fra poliklinikk til Nasjonalbiblioteket}

- Hvordan har det vært å lese disse historiene?

- Det har vært mye leting, en detektivprosess. Når jeg sitter på Riksarkivet og kommer over interessante ting, da forsvinner tiden for meg. Jeg kan ikke være i bedre flyt. Jeg blir grepet av det jeg leser. Jakten på kildemateriale er spennende. Man finner noen spor og leter videre.

- Hvor har du lett?

- Jeg har hatt forskerplass på Nasjonalbiblioteket i tre år. Katti Anker Møllers arkiv har vært viktig, og brev som de kvinnelige legene skrev, naturligvis. Og så datidens aviser og tidsskrifter, ikke minst kvinnetidsskriftene. På Riksarkivet har jeg også vært mye. Jeg har sett $\mathrm{i}$ arkivene til det medisinske fakultetet, forvaltningen, Rikshospitalet og ulike foreninger.

- Du satte deg ned med en avgrenset tidsperiode og begynte å grave i alle arkiver?

- Man lærer metoden etter hvert. Og av og til finner du noe annet enn det du leter etter. Det 
har vært morsomt å lete opp kilder og ha kontakt med slektninger av kvinnene og historielag. Så er oppgaven å formidle det man har funnet.

- Dette er ganske annerledes enn noe du har gjort før?

- Ja, det er det, selv om noe av skriveprosessen er det samme.

Ektemannen har også et skapende yrke - som musiker.

- Han forstår godt hva det dreier seg om når jeg er dypt inne i boblen.

De møttes på en blinddate som Vigdis Hjorth hadde arrangert, og mannen kan hente fram både datoen og klokkeslettet de traff hverandre. De har vært sammen siden de møttes første gang.

- Hva vil du gjøre videre?

- For det første har jeg en jobb som jeg liker godt. Den har jeg lyst til å videreutvikle. Jeg er blitt godt kjent med Norges første kvinnelige leger, så vi får se, sier hun og ler.

- Rett etter et stort arbeid er det godt å hvile litt.

Publisert: 11. januar 2019. Tidsskr Nor Legeforen. DOI: 10.4045/tidsskr.18.080o

(C) Tidsskrift for Den norske legeforening 2020. Lastet ned fra tidsskriftet.no 